\title{
Upgrading the hot water supply system as a way to save energy
}

\author{
Guzel Akhmerova ${ }^{1 *[0000-0003-4030-8264]}$, Alina Zalyalova ${ }^{2}$, Roman Badrutdinov ${ }^{1}$, Elza \\ Khaziakhmetova $^{3}$, and Rashid Maksudov ${ }^{4}$ \\ ${ }^{1}$ Kazan State University of Architecture and Engineering, 420043, Zelenaya st., Kazan, Russia \\ ${ }^{2}$ Joint-stock company Kazenergo, 420021, Gabdulla Tukay st., 162, Kazan, Russia \\ ${ }^{3}$ Kazan State Power Engineering University, 420066, Krasnoselskaya st., 51, Kazan, Russia \\ ${ }^{4}$ Kazan National Research Technological University, 420015, Karl Marks st., 68, Kazan, Russia
}

\begin{abstract}
The efficiency of works on replacement of steel pipelines of hot water supply of Kazan with pipes from polymer materials was considered. Due to the high corrosive activity of water, the service life of hot water pipelines does not exceed 8-10 years. To improve the reliability and quality of the supply of hot water to consumers, the possibility of modernizing hot water supply networks using pipelines made of polymer materials is being considered. The problem of physical wear of heat supply networks is disclosed; analysis of polymer pipelines use for energy saving purposes is carried out. Thermal energy savings are calculated after the modernization of heating networks. The costs, savings and payback period of the energysaving measures are determined.
\end{abstract}

Keywords: district heating systems, heat losses, thermal energy savings.

\section{Introduction}

Russia ranks first in the world in the development of heating, the length of heating networks and fuel costs in district heating systems. The adoption of federal and regional regulations in the field of energy conservation indicates the existence of problems in the thermal power sector. The objectives of improving energy efficiency and energy saving of such critical building engineering systems as heat supply and ventilation are considered by many researchers [1-6].

Most works on energy conservation consider the tasks of reducing the price of energy and dependence on fossil fuels, the use of renewable energy sources and CHP waste [7-12] and reduction of heat losses during transportation [13-16], influence of insulation thickness on cost parameters and corresponding savings in heat supply system [14, 17], reducing air pollution and actually saving carbon emissions [18], environmental impact of district heating systems and determination of combustion products parameters [17, 19-23]. Improvement of energy efficiency of heat supply systems of Russian cities when replacing central heat points with individual heat points is considered in the work [24], identification and disclosure of the main problems of deterioration of the quality of thermal protection of buildings, increase of thermal losses [25]. Studies [26-28] show the possibility of using

${ }^{*}$ Corresponding author: akhmerovaag@mail.ru 
pipelines from polymer materials with high-efficiency heat insulation in district heat supply systems.

The Russian network of urban housing and communal services is one of the largest in the world. Obviously, such a large and long system was created for decades, and the peak of the construction of centralized communications in the city housing and communal services occurred in the 1960s and 1980s. Centralized heating and hot-water supply are relatively young systems that were massively developed only in the 1970s. Nevertheless, the condition of heat networks made of traditional materials (metals) is in some cases even worse than that of pressure networks, for example, for cold water. It refers to water parameters. High temperature and pressure accelerate all chemical processes, including corrosion of pipeline walls, which can be both internal and external. Internal corrosion is caused by active substances dissolved in water, mainly oxygen and chlorine. Poor or nonexistent water treatment leads to leakage of pipes several years after their installation. Another problem of the heat supply is external corrosion, which is caused by damage to the layer of heat insulation material and penetration of atmospheric or ground moisture into the interior. Electrochemical corrosion is also a serious problem. If there is no protection against wandering currents in the heat network, the pipes will be destroyed much earlier than the set time. All this means that the hot-water supply pipes and heating systems fail much earlier than the regulatory period. There are cases when new pipes completely fail in two or three years.

Of course, utility networks, which were built mainly in the 1960-1980s, have already exceeded the threshold of standard life in a significant proportion of their length. The key indicator here is the share of the network in the corresponding category, which is operated with wear of more than $60 \%$ of the total length of the network. In 2018, the total length of heat networks in two-tube terms, the service life of which exceeded the normative one, amounted to $487007 \mathrm{~km}$. In addition, the dynamics of depreciation indicators significantly exceeds the dynamics of the development of the network. In recent years, the length of heat networks with wear of more than $60 \%$ has increased by $1.2 \%$.

It is understood that under the conditions described above, the main objective of municipalities is to urgently reduce the share of the fund operated with wear of $60+\%$ by replacing the corresponding sections of the pipeline with new ones. Improving the efficiency of district heating is one of the main factors in the development of the heat supply industry. Today, the high temperature and pressure in the main pipelines of the heating networks does not allow the use of available polymeric materials for their manufacture. But in quarterly networks, where the temperature rarely exceeds $115{ }^{\circ} \mathrm{C}$, the use of pipes made of polymeric materials is possible. The service life of polymer hot water pipelines is at least 30 years -3 times more than steel pipelines. When installing these pipes, the volume of work is 3-10 times less compared to traditional metal pipes. Installation costs are 5-10 times lower. Repair of pipeline damage takes a few hours. Repair and maintenance costs are reduced by 2-3 times. Therefore, replacing hot water steel pipelines with polypropylene will reduce the cost of the enterprise for repairs and their replacement in the future.

The purpose of the study is to substantiate the energy efficiency of modernization of hot water supply networks in Kazan. The following results of modernization of networks using polymer pipeline systems will be considered: improving the efficiency of heat supply systems; savings and payback period of the energy saving measures under consideration. 


\section{Materials and methods}

The calculation of thermal losses was calculated in two ways: according to the normalized heat losses in the thermal network and based on thermal technical formulas taking into account the state of the thermal insulation material.

The procedure for determining the standards for technological losses during the transfer of thermal energy with water, steam and condensate is set out in the order of the Ministry of Energy of Russia No. 325 (30.12.2008) «On approval of the procedure for determining the standards for technological losses during the transfer of thermal energy, coolant». This order also lists the standard losses from the pipeline depending on its diameter, type and year of laying and temperature of the transferred coolant.

Losses of the heating network include losses of the coolant itself - water (Fig. 1) and losses of thermal energy (Fig. 2), both with the coolant and through insulation.

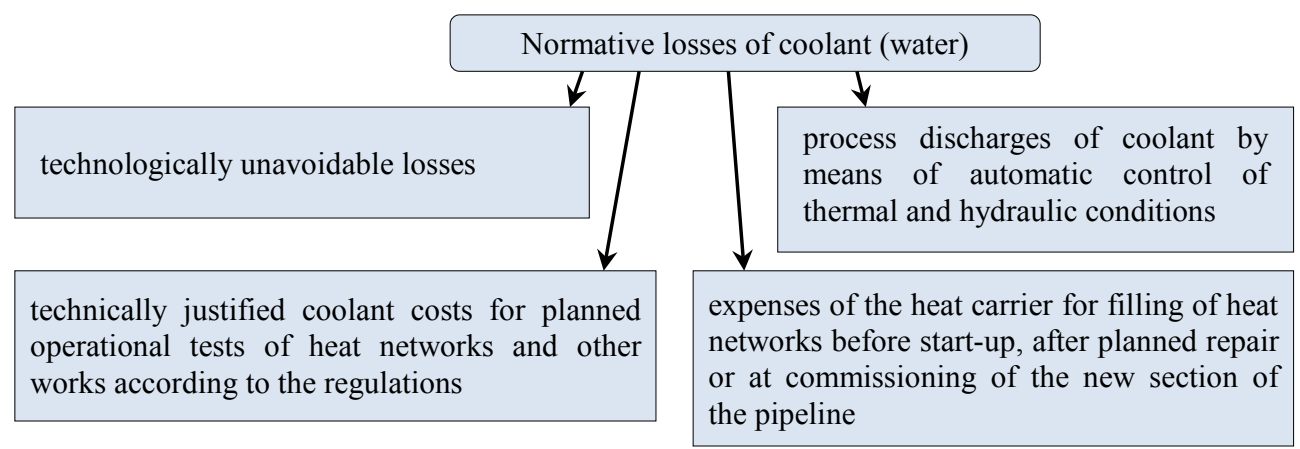

Fig. 1. Subtypes of water losses according to regulatory documents.

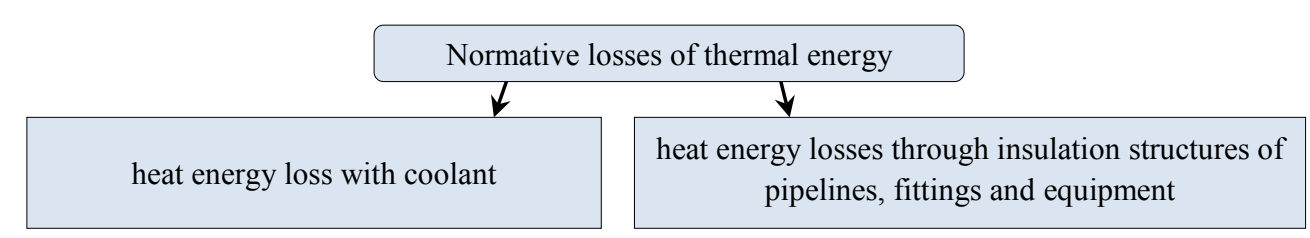

Fig. 2. Subtypes of normative heat losses according to regulatory documents.

For thermal calculation of insulation, equations of stationary heat transfer for a curved single-layer structure are used:

curvilinear n-layer:

$$
\mathrm{q}_{\mathrm{L}}=\frac{\mathrm{t}_{\mathrm{B}}-\mathrm{t}_{\mathrm{e}}}{\mathrm{R}_{\mathrm{B}}^{\mathrm{L}}+\mathrm{R}_{\mathrm{w}}^{\mathrm{L}}+\mathrm{R}_{\mathrm{is}}^{\mathrm{L}}+\mathrm{R}_{\mathrm{e}}^{\mathrm{L}}}
$$

$$
\mathrm{q}_{\mathrm{L}}=\frac{\mathrm{t}_{\mathrm{B}}-\mathrm{t}_{\mathrm{e}}}{\mathrm{R}_{\mathrm{B}}^{\mathrm{L}}+\mathrm{R}_{\mathrm{w}}^{\mathrm{L}}+\sum_{\mathrm{i}=1}^{\mathrm{n}} \mathrm{R}_{\mathrm{i}}^{\mathrm{L}}+\mathrm{R}_{\mathrm{e}}^{\mathrm{L}}}
$$

where $\mathrm{q}_{\mathrm{L}}$ - linear density of heat flow through cylindrical heat insulation structure, $\mathrm{W} / \mathrm{m}$;

$\mathrm{t}_{\mathrm{B}}$ - temperature of the medium inside the insulated equipment, ${ }^{\circ} \mathrm{C}$;

$\mathrm{t}_{\mathrm{e}}$ - ambient temperature, ${ }^{\circ} \mathrm{C}$;

$\mathrm{R}_{\mathrm{B}}^{\mathrm{L}}$ - linear thermal resistance to heat removal of the inner wall of the insulated object, $\mathrm{m} \cdot{ }^{\circ} \mathrm{C} / \mathrm{W}$;

$\mathrm{R}_{\mathrm{e}}^{\mathrm{L}}$ - linear thermal resistance to heat removal of external insulation, $\mathrm{m} \cdot{ }^{\circ} \mathrm{C} / \mathrm{W}$ :

$$
\mathrm{R}_{\mathrm{e}}^{\mathrm{L}}=\frac{1}{\pi \cdot \mathrm{d}_{\mathrm{H}}^{\mathrm{u3}} \cdot \alpha_{\mathrm{e}}}
$$


where $d_{\mathrm{H}}^{\text {из }}-$ external diameter of insulation, $\mathrm{m}$;

$\alpha_{e}$ - heat transfer coefficient of external insulation surface, $\mathrm{W} / \mathrm{m}^{2} \cdot{ }^{\circ} \mathrm{C}$;

$\mathrm{R}_{\mathrm{w}}^{\mathrm{L}}$ - linear thermal resistance to conductive heat transfer of cylindrical wall of insulated object, $\mathrm{m} \cdot{ }^{\circ} \mathrm{C} / \mathrm{W}$;

$\mathrm{R}^{\mathrm{L}}{ }_{\text {is }}$ - linear thermal resistance to conductive heat transfer of cylindrical insulation layer, $\mathrm{m} \cdot{ }^{\circ} \mathrm{C} / \mathrm{W}$ :

$$
\mathrm{R}_{i s}^{\mathrm{L}}=\frac{1}{2 \cdot \pi \cdot \lambda_{i s}} \cdot \ln \frac{\mathrm{d}_{\mathrm{H}}^{\text {из }}}{\mathrm{d}_{\mathrm{H}}},
$$

where $\lambda_{\text {is }}$ - thermal conductivity coefficient of insulation material, $\mathrm{W} / \mathrm{m} \cdot{ }^{\circ} \mathrm{C}$;

$\mathrm{d}_{\mathrm{H}}-$ outer diameter of insulated pipeline, $\mathrm{m}$;

$\sum_{\mathrm{i}=1}^{\mathrm{n}} \mathrm{R}_{\mathrm{i}}^{\mathrm{L}}$ - total linear thermal resistance to conductive heat transfer of n-layer cylindrical insulation, $\mathrm{m} \cdot{ }^{\circ} \mathrm{C} / \mathrm{W}$.

The main characteristic of thermal insulation structures of underground pipelines is their contact with the mass of the surrounding soil, which significantly complicates their thermal calculation compared to structures that are in contact with the atmosphere. The analysis of temperature fields and heat flows in thermal insulation structures and in soil made it possible to conclude that the temperature field directly in thermal insulation can be considered as one-dimensional with sufficient accuracy for technical calculations. This will determine their thermal resistance by formulae 1-4.

The density of heat flow through thermal insulation structures bordering the soil is determined in this case by formulae $1-2$, in which the thermal resistance to external heat transfer is $\mathrm{R}_{\mathrm{H}}^{\mathrm{L}}$ replaced by the thermal resistance of the soil. The analysis of heat exchange features in thermal insulation structures allows simplifying design formulas significantly.

The thermal resistance to heat transfer from the inner medium to the inner wall surface of the insulated object $\mathrm{R}_{\mathrm{BH}}^{\mathrm{L}}$ for liquid and even gaseous media compared to the thermal resistance to conductive heat transfer in the insulation $\mathrm{R}_{\mathrm{is}}^{\mathrm{L}}$ is insignificant and may not be taken into account.

The walls of insulated pipelines are usually made of metal, the thermal conductivity of which is 100 times or more higher than the thermal conductivity of insulation, as a result of which the thermal resistance of the wall of the $R_{w}^{L}$ can be neglected without a noticeable decrease in calculation accuracy.

Thus, the main calculation formula for determining the thermal losses of insulated pipelines is:

$$
\mathrm{q}_{\mathrm{L}}=\frac{\mathrm{t}_{\mathrm{B}}-\mathrm{t}_{\mathrm{e}}}{\sum_{\mathrm{i}=1}^{\mathrm{n}} \mathrm{R}_{\mathrm{i}}^{\mathrm{L}}+\mathrm{R}_{\mathrm{e}}^{\mathrm{L}}} \cdot \mathrm{K},
$$

where $\mathrm{K}$ - coefficient of additional losses, which takes into account heat loss through heatconducting inclusions in heat-insulating structures, due to the presence of fasteners and supports in them.

\section{Results and discussion}

Consider a four-tube heat supply system from the Central Technical Center of Kazenergo JSC, located at 43 Revolutionary St., Kazan, Kirovsky District. The diagram of the heat network is shown in Figure 3. The source of heat supply is the boiler room on the street. Zheleznodorozhnikov, 19. The temperature schedule of network of heating is $95 / 70{ }^{\circ} \mathrm{C}$, hotwater supply $-65 / 45^{\circ} \mathrm{C}$. The heat supply network serves four residential buildings with administrative premises and one administrative building on the street. Polytechnic, 3a indoor skating rink (Table 1). 
Table 1. Residential buildings connected to the central heating station.

\begin{tabular}{|l|c|c|c|}
\hline \multicolumn{1}{|c|}{ Consumer address } & $\begin{array}{c}\text { Number of } \\
\text { floors }\end{array}$ & Year of construction & $\begin{array}{c}\text { Number of } \\
\text { apartments }\end{array}$ \\
\hline Biryuzovaya, 1a & 10 & 2003 & 218 \\
\hline Revolyutsionnaya, 39 & 14 & 1986 & 78 \\
\hline Revolyutsionnaya, 41 & 14 & 1984 & 82 \\
\hline Ilyich, 19/43 & 9 & 1982 & 377 \\
\hline
\end{tabular}

The total length of the network is $616.5 \mathrm{~m}$ in four-tube calculus. Steel pipelines in polyurethane foam insulation without channel gasket. The depth of laying to the axis of pipelines is $1.6 \mathrm{~m}$. The heating pipes were repaired in 2003 and the hot water pipes were installed in 2010. The clay soil has the following characteristics: average density of soil $1300 \mathrm{~kg} / \mathrm{m}^{3}$, weight moisture content of soil - 32\% (wet soil).

Calculations were carried out for the following cases:

1-2. Heat station - central, four-tube heat supply system, coolant parameters for heating system pipelines $\mathrm{T} 1 / \mathrm{T} 2-95 / 70{ }^{\circ} \mathrm{C}$, hot water supply pipelines $\mathrm{T} 3 / \mathrm{T} 4-65 / 45^{\circ} \mathrm{C}$.

3-4. Heat station - central, four-tube heat supply system, coolant parameters for heating system pipelines $\mathrm{T} 1 / \mathrm{T} 2-115 / 70{ }^{\circ} \mathrm{C}$, hot water supply pipelines $\mathrm{T} 3 / \mathrm{T} 4-65 / 45^{\circ} \mathrm{C}$.

5-6. Heat station - individual, the system of heat supply two-pipe, heat carrier parameters for the wasps pipelines $95 / 70,115 / 70{ }^{\circ} \mathrm{C}$.

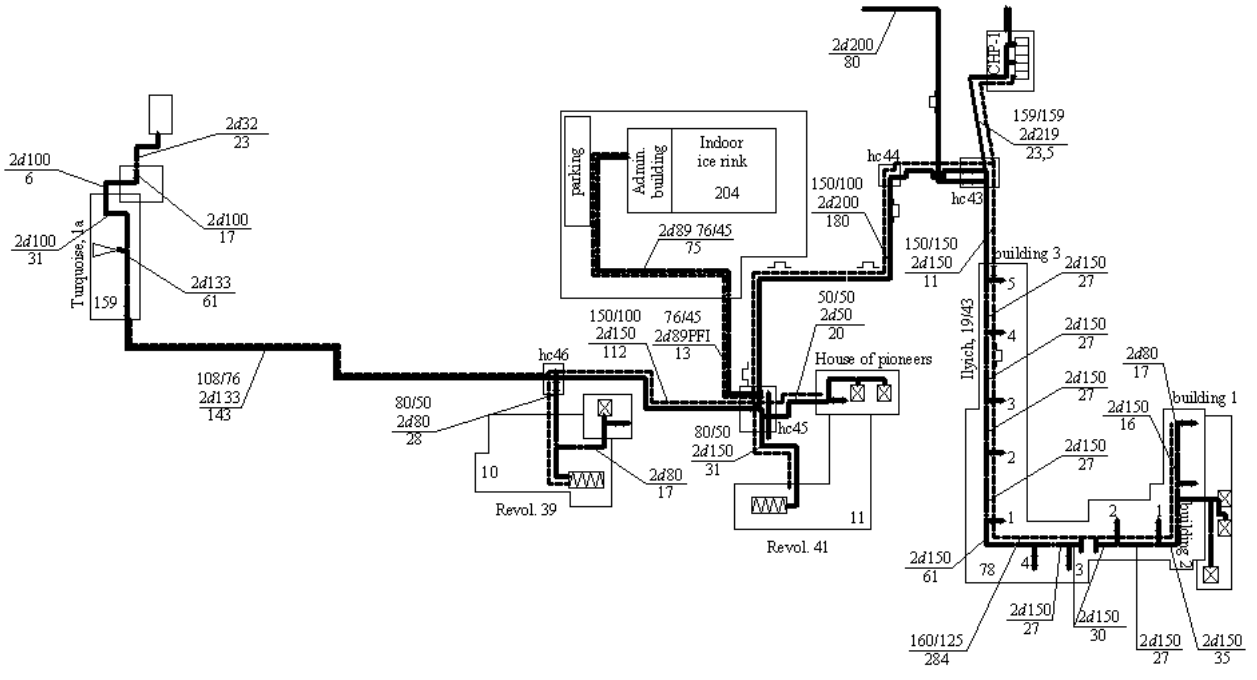

Fig. 3. Diagram of heat networks from the central heat point on the Revolyutsionnaya str., 43.

The initial data for thermal loss calculations are presented in Table 2.

Comparison of the results obtained in Table 3 shows that the heat losses determined by the standard are more than the losses determined by the heat engineering formulas taking into account the correction for the technical condition of the heat insulation material. 
Table 2. Initial data for calculation of thermal losses through insulation.

\begin{tabular}{|c|c|c|c|c|c|c|c|}
\hline \multirow{2}{*}{$\begin{array}{c}\text { Calcu- } \\
\text { lation } \\
\text { numb } \\
\text { er }\end{array}$} & \multirow{2}{*}{$\begin{array}{l}\text { Heat } \\
\text { station }\end{array}$} & \multirow{2}{*}{$\begin{array}{c}\text { The } \\
\text { tempera } \\
\text {-ture } \\
\text { sche- } \\
\text { dule }{ }^{\circ} \mathrm{C}\end{array}$} & \multirow{2}{*}{$\begin{array}{c}\text { Type of } \\
\text { gasket }\end{array}$} & \multicolumn{2}{|c|}{ Piping material } & \multicolumn{2}{|c|}{$\begin{array}{c}\text { The year of } \\
\text { laying (repair) } \\
\text { of pipelines }\end{array}$} \\
\hline & & & & $\mathrm{T} 1 / \mathrm{T} 2$ & $\mathrm{~T} 3 / \mathrm{T} 4$ & $\mathrm{~T} 1 / \mathrm{T} 2$ & $\mathrm{~T} 3 / \mathrm{T} 4$ \\
\hline 1 & \multirow{4}{*}{$\begin{array}{l}\text { Heat } \\
\text { station - } \\
\text { central }\end{array}$} & $95 / 70$ & Channel-free & \multirow{6}{*}{$\begin{array}{c}\text { Steel in } \\
\text { polyurethane } \\
\text { foam insulation }\end{array}$} & $\begin{array}{c}\text { Steel in } \\
\text { polyurethane } \\
\text { foam insulation }\end{array}$ & 2003 & 2010 \\
\hline 2 & & $95 / 70$ & Channel-free & & Isoproflex & 2003 & 2020 \\
\hline 3 & & $115 / 70$ & Channel-free & & $\begin{array}{c}\text { Steel in } \\
\text { polyurethane } \\
\text { foam insulation }\end{array}$ & 2003 & 2010 \\
\hline 4 & & $115 / 70$ & Channel-free & & Isoproflex & 2003 & 2020 \\
\hline 5 & \multirow{2}{*}{$\begin{array}{c}\text { Heat } \\
\text { station - } \\
\text { individual }\end{array}$} & $95 / 70$ & Channel-free & & - & 2020 & - \\
\hline 6 & & $115 / 70$ & Channel-free & & - & 2020 & - \\
\hline
\end{tabular}

Table 3. Results of calculation of thermal losses through insulation.

\begin{tabular}{|c|c|c|c|c|c|c|}
\hline \multirow{2}{*}{$\begin{array}{c}\text { Calculati } \\
\text { on no. }\end{array}$} & \multicolumn{5}{|c|}{ Thermal losses through insulation, Gcal/year } \\
\cline { 2 - 7 } & \multicolumn{3}{|c|}{ standard (normative) } & \multicolumn{3}{c|}{$\begin{array}{c}\text { calculated, according to heat } \\
\text { engineering formulas }\end{array}$} \\
\cline { 2 - 7 } & T1/T2 & T3/T4 & total & T1/T2 & T3/T4 & total \\
\hline 1 & 143.94 & 239.17 & 383.11 & 148.41 & 215.58 & 363.99 \\
\hline 2 & 143.94 & 229.17 & 373.11 & 148.41 & 187.37 & 335.78 \\
\hline 3 & 150.07 & 239.17 & 389.24 & 162.46 & 215.58 & 378.04 \\
\hline 4 & 150.07 & 229.17 & 379.24 & 162.46 & 187.37 & 349.83 \\
\hline 5 & 383.17 & - & 383.17 & 317.11 & - & 317.11 \\
\hline 6 & 349.71 & - & 349.71 & 283.79 & - & 283.79 \\
\hline
\end{tabular}

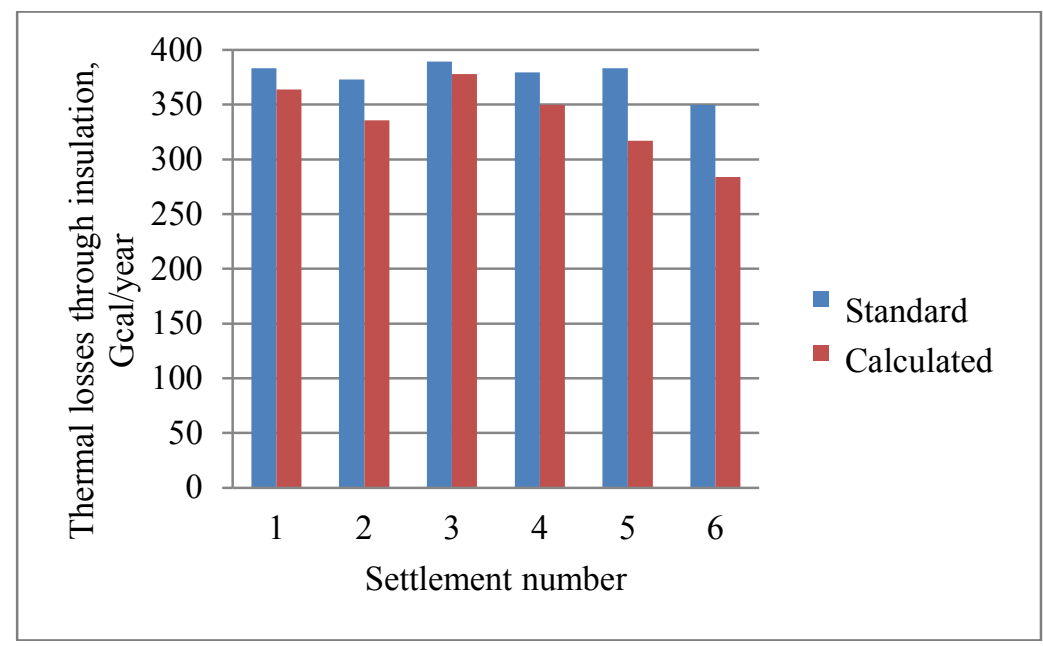

Fig. 4. Diagram of results of calculation of thermal losses through insulation. 
We will calculate the heat losses after the modernization of the hot-water supply networks using flexible polymer heat-insulated pipelines «Isoproflex-75A» made of cross-linked polyethylene (four-tube heat supply system). We will consider the thermal losses defined on the basis of heat technical calculation of networks of hot water supply from the central heat distribution station (T3/T4 with temperatures of heat carrier of $65 / 45^{\circ} \mathrm{C}$ ) (Fig. 5).

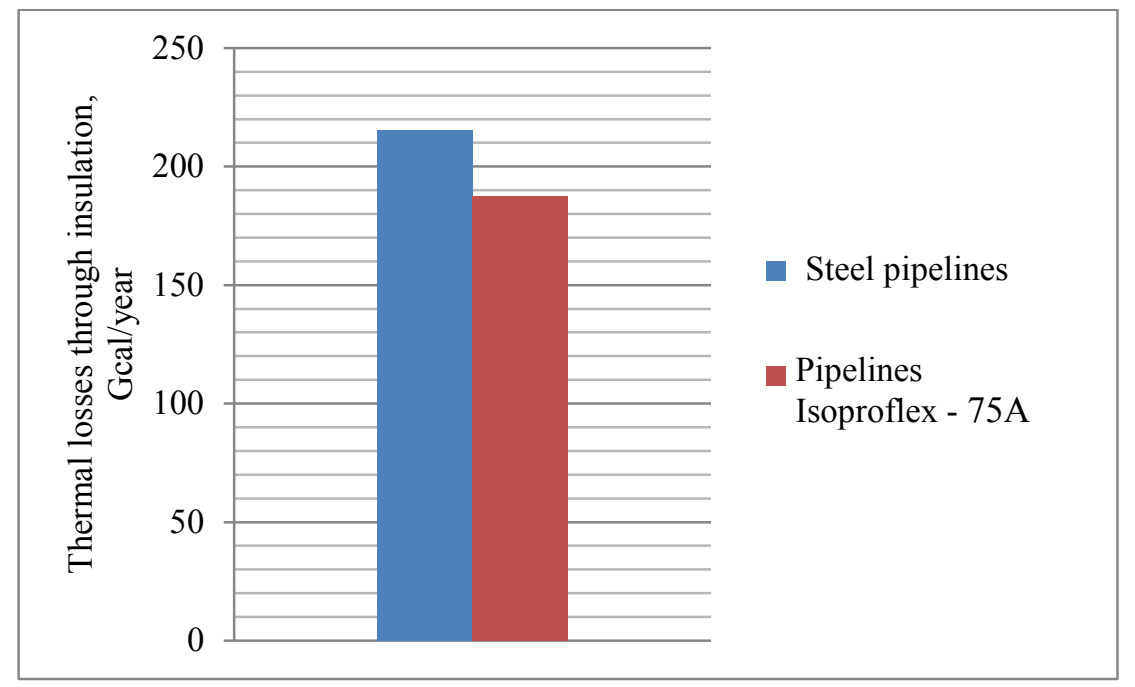

Fig. 5. Diagram of heat losses before and after modernization of hot water supply networks using flexible polymer heat insulated pipelines «Isoproflex-75A».

\subsection{Evaluating the effectiveness of energy-saving measures}

On the example of the heat supply system from the central heat station of Kazenergo JSC to existing consumers, we will evaluate two energy-saving measures:

1. Modernization of hot water supply networks using Isoproflex polymer pipelines.

2. Change from Central Heat Point (CHP) to Individual Heat Point (IHP).

The efficiency of the energy-saving measures under consideration was evaluated: costs, savings and payback period were calculated. The evaluation results are shown in Table 4. We will determine the most effective of them.

Thus, the cost of switching from a central heat point to an individual heat point for $95 / 70{ }^{\circ} \mathrm{C}$ and $115 / 70{ }^{\circ} \mathrm{C}$ temperature schedules will amount to 28398154 thousand rubles/year and 23785210 thousand rubles/year, respectively, and savings - 1970342 thousand rubles/year and 2012 655. The payback period of this energy saving event is 14 years, 5 months and 11 years, 10 months.

The most effective energy saving activity is the modernization of hot water supply networks using flexible polymer heat-insulated pipelines «Isoproflex-75A» (four-tube heat supply system). Costs for it will amount to 14353174 thousand rubles/year, and savings 1220283 thousand rubles/year. Modernization of hot water supply networks using Isoproflex-75A will pay off in 10 years and 2 months. 
Table 4. Evaluating the effectiveness of energy-saving measures

\begin{tabular}{|c|c|c|c|c|}
\hline \multirow{7}{*}{ Indicator } & \multicolumn{4}{|c|}{ Energy-saving measures } \\
\hline & \multicolumn{2}{|c|}{$\begin{array}{l}\text { Reconstruction of hot water } \\
\text { supply networks using } \\
\text { Isoproflex-75A pipelines }\end{array}$} & \multicolumn{2}{|c|}{$\begin{array}{l}\text { Change from Central Heat Point } \\
\text { (CHP) to Individual Heat Point } \\
\text { (IHP) (from four-pipe heat } \\
\text { supply system to two-pipe) }\end{array}$} \\
\hline & \multicolumn{4}{|c|}{ The temperature schedule, ${ }^{\circ} \mathrm{C}$} \\
\hline & \multicolumn{2}{|c|}{$65 / 45$} & $95 / 70$ & $115 / 70$ \\
\hline & \multicolumn{4}{|c|}{ Review period, year } \\
\hline & 1 & 30 & 1 & 1 \\
\hline & \multicolumn{4}{|c|}{ Cost with value added tax VAT, thousand rubles } \\
\hline $\begin{array}{l}\text { Reconstruction of } \\
\text { hot water supply } \\
\text { networks }\end{array}$ & 12399.510 & 12399.510 & - & - \\
\hline $\begin{array}{l}\text { Reconstruction of } \\
\text { heat networks }\end{array}$ & - & - & 9677.395 & 5064.451 \\
\hline $\begin{array}{lr}\text { Construction } & \text { of } \\
\text { Individual } & \text { Heat } \\
\text { Point (IHP) } & \\
\end{array}$ & - & - & \multicolumn{2}{|c|}{18720.759} \\
\hline $\begin{array}{l}\text { Operation of CHP } \\
\text { Central Heat Point }\end{array}$ & 1953.664 & 58609.920 & \multicolumn{2}{|r|}{ - } \\
\hline \multirow[t]{2}{*}{ Total } & 14353.174 & 71009.430 & 28398.154 & 23785.210 \\
\hline & \multicolumn{4}{|c|}{ Savings with VAT, thousand rubles } \\
\hline $\begin{array}{l}\text { Reduction of } \\
\text { thermal losses } \\
\text { through insulation }\end{array}$ & -25.199 & -755.970 & -16.678 & -58.991 \\
\hline $\begin{array}{l}\text { Operation of CHP } \\
\text { Central Heat Point }\end{array}$ & - & - & \multicolumn{2}{|c|}{-1953.664} \\
\hline $\begin{array}{l}\text { Reconstruction } \text { of } \\
\text { hot water steel } \\
\text { pipelines to in } \\
\text { polyurethane foam } \\
\text { insulation }\end{array}$ & -1195.084 & -35852.526 & - & - \\
\hline Total & -1220.283 & -36608.496 & -1970.342 & -2012.655 \\
\hline Payback period & \multicolumn{2}{|c|}{10 years and 2 months } & $\begin{array}{c}14 \text { years } \\
\text { and } 5 \text { months }\end{array}$ & $\begin{array}{l}11 \text { years and } \\
10 \text { months }\end{array}$ \\
\hline
\end{tabular}

\section{Conclusions}

Based on the data and materials of Kazenergo JSC, actual losses of thermal energy at the tested sections of the thermal network were calculated. Analyzing the results of heat loss calculations, it is obvious that the heat losses determined according to the standard are more than the losses determined according to the heat engineering formulas. Comparison of normative heat losses with their actual values made it possible to justify the effectiveness of work on replacing steel hot water pipelines with polypropylene ones and to assess the possible reduction in energy consumption and energy saving effect. 
The results of the analysis of the effectiveness of the energy-saving measures under consideration make it possible to draw the following conclusions:

when upgrading existing systems depending on the location of the central heating station, the state of the equipment building, the number of connected buildings and the prospect of maintaining the existing development, the reconstruction of hot water supply networks using flexible polymer heat-insulated pipelines should be considered;

In the new construction of residential buildings and administrative buildings, a two-pipe heat supply system with individual heat points should be used.

\section{References}

1. K. Wojdyga, M. Chorzelski, in Energy Procedia, 116, 106-118 (2017) DOI: 10.1016/j.egypro.2017.05.059.

2. S. Werner, Energy 137, 617-631 (2017). S. Werner, Energy (2017) DOI: 10.1016/j.energy.2017.04.045.

3. S. Werner, Energy, 126, 419-429 (2017) DOI: 10.1016/j.energy.2017.03.052

4. G. Deshmukh, P. Birwal, R. Datir, S. Patel, J. Food Process. Technol., 08, (04) (2017) DOI: $10.4172 / 2157-7110.1000670$

5. F. Safiullin, V. Broyda, IOP Conf. Ser.: Mater. Sci. Eng., 890, 012148 (2020) DOI: 10.1088/1757-899X/890/1/012148

6. R. Safiullin, J. Kareeva, IOP Conf. Ser.: Mater. Sci. Eng., 890, 012159 (2020) DOI: 10.1088/1757-899X/890/1/012159.

7. A. Dahash, F. Ochs, M. B. Janetti, W. Streicher, Appl. Energy 239, 296-315 (2019) DOI: 10.1016/j.apenergy.2019.01.189.

8. M. Gong, S. Werner, Renew. Energy, 84, 274-285 (2015) DOI: 10.1016/j.renene.2015.05.061

9. H. Averfalk, S. Werner, Energy, 193 (2020) DOI: 10.1016/j.energy.2019.116727

10. M. A. Taimarov, N. F. Timerbaev, Yu. V. Lavirko, Izvestija KGASU, 2(52), 98-105 (2020).

11. M. A. Taimarov, Yu. V. Lavirko, Izvestija KGASU, 2(56) (2021) (to be published)

12. N. Krasinikova, S. Stepanov, D. Makarov, IOP Conf. Ser.: Mater. Sci. Eng., 890, 012099 (2020) DOI: 10.1088/1757-899X/890/1/012099.

13. R. Zwierzchowski, O. Niemyjski, in IOP Conf. Ser. Mater. Sci. Eng., 471(4) (2019) DOI: $10.1088 / 1757-899 X / 471 / 4 / 042019$.

14. R. Lund, S. Mohammadi, in Appl. Therm. Eng., 98, 256-264 (2016) DOI: 10.1016/j.applthermaleng.2015.12.015

15. G. M. Akhmerova, A.R. Zalyalova, R.M. Mukhametshina, IOP Conf. Ser.: Mater. Sci. Eng. 890012153 (2020) DOI:10.1088/1757-899X/890/1/012153

16. G. M. Akhmerova, A. V. Fedorov, Izvestija KGASU, 2(36), 117-122 (2016)

17. A. Daşdemir, T. Ural, M. Ertürk, A. Keçebaş, Appl. Therm. Eng., 121, 242-254 (2017) DOI: $10.1016 /$ j.applthermaleng.2017.04.001

18. M. A. Sayegh, J. Danielewicz, T. Nannou, M. Miniewicz, P. Jadwiszczak, K. Piekarska, H. Jouhara, Renew. Sustain. Energy Rev., 68, 1183-1192 (2017) DOI: 10.1016/j.rser.2016.02.023

19. Y. Başoğul, C. Demircan, A. Keçebaş, Appl. Therm. Eng., 101, 121-130 (2016) DOI: 10.1016/j.applthermaleng.2016.03.010

20. H. Wang, H. Meng, T. Zhu, Energy Convers. Manag., 157, 71-85 (2018) DOI: 10.1016/j.enconman.2017.11.062

21. J. Danielewicz, B. Śniechowska, M. A. Sayegh, N. Fidorów, H. Jouhara, Energy, 108, 172-184 (2016) DOI: 10.1016/j.energy.2015.07.012 
22. R. Ovando-Castelar, J. I. Martínez-Estrella, A. García-Gutierrez, I. Canchola-Félix, P. Jacobo-Galván, C. Miranda-Herrera, O. Mora-Perez, Analysis of the Heat Losses in the Cerro Prieto Geothermal Field Transportation Network Based on Thermal Insulation Condition of Steam Pipelines: A Quantitative Assessment. World Geotherm. Congr. 2015 (2015).

23. O. Barysheva, R. Sadykov, IOP Conf. Ser.: Mater. Sci. Eng., 890, 012158 (2020) DOI: 10.1088/1757-899X/890/1/012158

24. N. D. Chichirova, I. G. Akhmetova, K. V. Lapin, A. R. Gilmanova, I. O. N. Ion, E3S Web Conf., (2019) DOI: 10.1051/e3sconf/201912404009

25. A. R. Mavlyuberdinov, R. N. Mukminov, IOP Conf. Ser.: Mater. Sci. Eng., 687, 033035 (2019). DOI: $10.1088 / 1757-899 X / 687 / 3 / 033035$

26. H. Lund, P. A. Østergaard, M. Chang, S. Werner, S. Svendsen, P. Sorknæs, J. E. Thorsen, F. Hvelplund, B. O. G. Mortensen, B. V. Mathiesen, C. Bojesen, N. Duic, X. Zhang, B. Möller, Energy (2018) DOI: 10.1016/j.energy.2018.08.206

27. I. Baldvinsson, T. Nakata, Energy, 95, 155-174 (2016) DOI: 10.1016/j.energy.2015.11.057

28. I.N. Solomin, A.Z. Daminov, R.A. Sadykov, Izvestija KGASU, 2(44), 184-192 (2018) 